\title{
Report:
}

\section{Civil Partnerships during 2008: United Kingdom}

\section{Introduction}

This update provides detailed findings from the Office for National Statistics publication Civil Partnerships 2008 published on 4 August 2009. It presents data and analysis on civil partnerships that took place in the UK in 2008. Particular attention is given to:

- number of civil partnerships and rates

- civil partnerships by sex

- age at formation

- $\quad$ area of formation

- previous legal partnership status

- civil partnership dissolutions

The annual tables are available at:

www.statistics.gov.uk/StatBase/Product.asp?vlnk=14675

\section{Number of civil partnerships}

The Civil Partnership Act 2004 came into force on 5 December 2005 in the UK, the first day couples could give notice of their intention to form a civil partnership. The Act enables same-sex couples aged 16 and over to obtain legal recognition of their relationship. The first day that couples could normally form a civil partnership was 19 December 2005 in Northern Ireland, 20 December 2005 in Scotland and 21 December 2005 in England and Wales. ${ }^{1}$

Table 1 shows the number of civil partnerships formed between December 2005 and the end of 2008 by country and sex. There were 7,169 civil partnerships formed in the UK in $2008,{ }^{2}$ a decrease of 18 per cent from 8,728 in 2007.

As in 2007, the majority of UK civil partnerships formed in 2008 were in England ( 88 per cent) followed by Scotland ( 7.3 per cent), Wales (3.9 per cent) and Northern Ireland (1.2 per cent). ${ }^{3}$ The corresponding proportions of the adult population residing in these countries were 84 per cent, 8.5 per cent, 4.9 per cent and 2.8 per cent. ${ }^{4}$

There was a decrease in civil partnerships between 2007 and 2008 in all four countries of the UK, with the largest in Scotland (24 per cent) and the smallest in Wales (4.1 per cent). In England and Northern Ireland, the number of civil partnerships fell by 18 per cent and 23 per cent respectively. There was a decrease of 10 per cent or more in each of the English regions with the largest decrease ( 23 per cent) seen in the North East.

The number of UK civil partnerships rose steadily from 1,248 in the first quarter of 2008 to a peak of 2,459 in the third quarter and fell to 1,531 in the fourth quarter, reflecting a seasonal trend similar to marriages.

\section{Rates}

Table 2 shows civil partnership rates for 2005 to 2008. Population estimates by marital status are only available for England and Wales (combined) and for Scotland; therefore rates can only be calculated for these countries. The rates are based on the number of people forming a civil partnership per year as a proportion of the population legally able to form a civil partnership. The population is defined as the number of men or women aged 16 and over living in England and Wales or Scotland, irrespective of sexual preference, who are currently not married. Ideally, this population should also exclude those that are already in a civil partnership; however civil partnership status is not included in the mid-year population estimates by marital status.

There were small decreases in the rates for civil partnerships for both men and women in 2008. In England and Wales, 0.7 men per 1,000 unmarried men aged 16 and over entered into a civil partnership in 2008 compared with 0.8 in 2007. The rate for women was 0.5 in 2008 compared with 0.6 in 2007. In Scotland, the civil partnership rate for men was 0.5 in 2008 compared with 0.7 in 2007 and for women it was 0.5 in 2008 compared with 0.6 in $2007 .^{5}$

\section{Civil partnerships by sex}

The proportions of male and female civil partnerships formed in the UK appear to be converging (Figure 1). Men formed 53 per cent of all UK civil partnerships in 2008 compared with 55 per cent in 2007. More men than women formed civil partnerships in England (54 per cent male); however, the situation was reversed in Scotland and in Wales 


\begin{tabular}{|c|c|c|c|c|c|c|c|c|c|c|c|c|c|c|c|c|}
\hline \multirow[b]{2}{*}{ Year } & \multirow[b]{2}{*}{ Quarter } & \multicolumn{3}{|c|}{ United Kingdom ${ }^{1}$} & \multicolumn{3}{|c|}{ England $^{1}$} & \multicolumn{3}{|c|}{ Wales $^{1}$} & \multicolumn{3}{|c|}{ Scotland ${ }^{1}$} & \multicolumn{3}{|c|}{ Northern Ireland ${ }^{1}$} \\
\hline & & Total & Male & Female & Total & Male & Female & Total & Male & Female & Total & Male & Female & Total & Male & Female \\
\hline \multirow[t]{4}{*}{$2005^{2}$} & Number & 1,953 & 1,287 & 666 & 1,790 & 1,195 & 595 & 67 & 33 & 34 & 84 & 53 & 31 & 12 & 6 & 6 \\
\hline & Per cent & 100 & 66 & 34 & 100 & 67 & 33 & 100 & 49 & 51 & 100 & 63 & 37 & 100 & 50 & 50 \\
\hline & Mean age ${ }^{3}$ & 51.2 & 53.9 & 46.1 & 51.6 & 54.0 & 46.5 & 46.4 & 51.3 & 41.6 & 51.3 & 53.1 & 45.4 & 37.1 & 39.4 & 34.7 \\
\hline & Median age $^{3}$ & 50.2 & 53.7 & 44.1 & 50.6 & 53.9 & 44.4 & 46.8 & 50.9 & 42.3 & 50.1 & 54.0 & 44.5 & 34.6 & 35.7 & 34.3 \\
\hline \multirow[t]{12}{*}{2006} & Number & 16,106 & 9,648 & 6,458 & 14,383 & 8,718 & 5,665 & 560 & 285 & 275 & 1,047 & 580 & 467 & 116 & 65 & 51 \\
\hline & Per cent & 100 & 60 & 40 & 100 & 61 & 39 & 100 & 51 & 49 & 100 & 55 & 45 & 100 & 56 & 44 \\
\hline & Quarter 1 & 4,869 & 3,198 & 1,671 & 4,418 & 2,913 & 1,505 & 161 & 97 & 64 & 259 & 167 & 92 & 31 & 21 & 10 \\
\hline & & 100 & 66 & 34 & 100 & 66 & 34 & 100 & 60 & 40 & 100 & 64 & 36 & 100 & 68 & 32 \\
\hline & Quarter 2 & 4,363 & 2,590 & 1,773 & 3,861 & 2,327 & 1,534 & 151 & 80 & 71 & 316 & 168 & 148 & 35 & 15 & 20 \\
\hline & & 100 & 59 & 41 & 100 & 60 & 40 & 100 & 53 & 47 & 100 & 53 & 47 & 100 & 43 & 57 \\
\hline & Quarter 3 & 4,492 & 2,505 & 1,987 & 4,018 & 2,276 & 1,742 & 159 & 65 & 94 & 284 & 145 & 139 & 31 & 19 & 12 \\
\hline & & 100 & 56 & 44 & 100 & 57 & 43 & 100 & 41 & 59 & 100 & 51 & 49 & 100 & 61 & 39 \\
\hline & Quarter 4 & 2,382 & 1,355 & 1,027 & 2,086 & 1,202 & 884 & 89 & 43 & 46 & 188 & 100 & 88 & 19 & 10 & 9 \\
\hline & & 100 & 57 & 43 & 100 & 58 & 42 & 100 & 48 & 52 & 100 & 53 & 47 & 100 & 53 & 47 \\
\hline & Mean age ${ }^{3}$ & 45.6 & 47.0 & 43.6 & 45.8 & 47.1 & 43.7 & 45.3 & 47.9 & 42.7 & 44.4 & 45.6 & 43.0 & 41.3 & 42.7 & 39.5 \\
\hline & Median age ${ }^{3}$ & 44.3 & 45.4 & 42.6 & 44.4 & 45.5 & 42.7 & 44.5 & 47.4 & 42.2 & 43.2 & 43.9 & 42.3 & 40.2 & 41.1 & 39.5 \\
\hline \multirow[t]{12}{*}{2007} & Number & 8,728 & 4,770 & 3,958 & 7,635 & 4,242 & 3,393 & 294 & 129 & 165 & 688 & 339 & 349 & 111 & 60 & 51 \\
\hline & Per cent & 100 & 55 & 45 & 100 & 56 & 44 & 100 & 44 & 56 & 100 & 49 & 51 & 100 & 54 & 46 \\
\hline & Quarter 1 & 1,686 & 962 & 724 & 1,493 & 867 & 626 & 59 & 34 & 25 & 112 & 49 & 63 & 22 & 12 & 10 \\
\hline & & 100 & 57 & 43 & 100 & 58 & 42 & 100 & 58 & 42 & 100 & 44 & 56 & 100 & 55 & 45 \\
\hline & Quarter 2 & 2,366 & 1,262 & 1,104 & 2,058 & 1,112 & 946 & 99 & 40 & 59 & 180 & 93 & 87 & 29 & 17 & 12 \\
\hline & & 100 & 53 & 47 & 100 & 54 & 46 & 100 & 40 & 60 & 100 & 52 & 48 & 100 & 59 & 41 \\
\hline & Quarter 3 & 2,963 & 1,536 & 1,427 & 2,602 & 1,369 & 1,233 & 78 & 30 & 48 & 245 & 119 & 126 & 38 & 18 & 20 \\
\hline & & 100 & 52 & 48 & 100 & 53 & 47 & 100 & 38 & 62 & 100 & 49 & 51 & 100 & 47 & 53 \\
\hline & Quarter 4 & 1,713 & 1,010 & 703 & 1,482 & 894 & 588 & 58 & 25 & 33 & 151 & 78 & 73 & 22 & 13 & 9 \\
\hline & & 100 & 59 & 41 & 100 & 60 & 40 & 100 & 43 & 57 & 100 & 52 & 48 & 100 & 59 & 41 \\
\hline & Mean age ${ }^{3}$ & 42.1 & 42.8 & 41.2 & 42.1 & 42.8 & 41.2 & 42.2 & 43.9 & 40.9 & 41.9 & 42.5 & 41.3 & 39.7 & 41.1 & 38.0 \\
\hline & Median age 3 & 40.9 & 41.5 & 40.3 & 40.9 & 41.5 & 40.3 & 41.9 & 42.7 & 40.9 & 41.2 & 41.3 & 41.0 & 39.1 & 40.3 & 38.1 \\
\hline \multirow[t]{12}{*}{$2008^{p}$} & Number & 7,169 & 3,824 & 3,345 & 6,276 & 3,399 & 2,877 & 282 & 137 & 145 & 525 & 245 & 280 & 86 & 43 & 43 \\
\hline & Per cent & 100 & 53 & 47 & 100 & 54 & 46 & 100 & 49 & 51 & 100 & 47 & 53 & 100 & 50 & 50 \\
\hline & Quarter 1 & 1,248 & 704 & 544 & 1,077 & 609 & 468 & 55 & 32 & 23 & 98 & 54 & 44 & 18 & 9 & 9 \\
\hline & & 100 & 56 & 44 & 100 & 57 & 43 & 100 & 58 & 42 & 100 & 55 & 45 & 100 & 50 & 50 \\
\hline & Quarter 2 & 1,931 & 1,034 & 897 & 1,723 & 939 & 784 & 71 & 30 & 41 & 114 & 53 & 61 & 23 & 21 & 11 \\
\hline & & 100 & 54 & 46 & 100 & 54 & 46 & 100 & 42 & 58 & 100 & 46 & 54 & 100 & 52 & 48 \\
\hline & Quarter 3 & 2,459 & 1,244 & 1,215 & 2,143 & 1,105 & 1,038 & 98 & 46 & 52 & 195 & 83 & 112 & 23 & 10 & 13 \\
\hline & & 100 & 51 & 49 & 100 & 52 & 48 & 100 & 47 & 53 & 100 & 43 & 57 & 100 & 43 & 57 \\
\hline & Quarter 4 & 1,531 & 842 & 689 & 1,333 & 746 & 587 & 58 & 29 & 29 & 118 & 55 & 63 & 22 & 12 & 10 \\
\hline & & 100 & 55 & 45 & 100 & 56 & 44 & 100 & 50 & 50 & 100 & 47 & 53 & 100 & 55 & 45 \\
\hline & Mean age $\mathrm{e}^{3}$ & 40.9 & 41.8 & 40.0 & 40.9 & 41.8 & 39.9 & 40.6 & 41.8 & 39.5 & 40.9 & 41.3 & 40.6 & 39.3 & 40.6 & 37.9 \\
\hline & Median age $^{3}$ & 39.7 & 40.3 & 38.9 & 39.8 & 40.3 & 38.9 & 39.8 & 40.9 & 37.8 & 39.8 & 40.0 & 39.7 & 38.8 & 40.4 & 37.4 \\
\hline
\end{tabular}

1 Data are based on country of formation and not country of residence.

2 The Civil Partnership Act 2004 came into force on 5 December 2005 in the UK.

3 The mean and median ages shown in this table are not standardised and therefore take no account of the structure of the population by age or legal partnership status.

p Figures for Northern Ireland and the UK for 2008 are provisional.

Source: www.statistics.gov.uk/StatBase/Product.asp?vink=14675 Tables 1 and 7

(47 and 49 per cent male respectively). In Northern Ireland there were equal numbers of male and female partnerships.

Figure 2 shows the number of civil partnerships formed in 2008 by region and sex. With almost three out of four (74 per cent) civil partnerships to men, London remained, by far, the UK region with the largest proportion of male civil partnerships. With almost three out of five civil partnerships ( 58 per cent) formed by women, the North East was the region with the largest proportion of female civil partnerships. 


\begin{tabular}{|c|c|c|c|c|c|c|c|}
\hline \multirow[b]{2}{*}{ Year } & \multirow[b]{2}{*}{ Quarter } & \multicolumn{3}{|c|}{ England and Wales ${ }^{1}$} & \multicolumn{3}{|c|}{ Scotland ${ }^{1}$} \\
\hline & & Total & Male & Female & Total & Male & Female \\
\hline \multirow[t]{2}{*}{$2005^{2}$} & Number of civil partnerships & 1,857 & 1,228 & 629 & 84 & 53 & 31 \\
\hline & $\begin{array}{l}\text { People forming a civil partnership per } \\
1,000 \text { unmarried population aged } 16 \text { and over }\end{array}$ & 5.7 & 8.0 & 3.7 & 2.5 & 3.5 & 1.7 \\
\hline \multirow[t]{10}{*}{2006} & Number of civil partnerships & 14,943 & 9,003 & 5,940 & 1,047 & 580 & 467 \\
\hline & $\begin{array}{l}\text { People forming a civil partnership per } \\
1,000 \text { unmarried population aged } 16 \text { and over }\end{array}$ & 1.4 & 1.8 & 1.0 & 1.0 & 1.2 & 0.8 \\
\hline & Quarter 1 & 4,579 & 3,010 & 1,569 & 259 & 167 & 92 \\
\hline & & 1.7 & 2.4 & 1.1 & 1.0 & 1.4 & 0.7 \\
\hline & Quarter 2 & 4,012 & 2,407 & 1,605 & 316 & 168 & 148 \\
\hline & & 1.5 & 1.9 & 1.1 & 1.2 & 1.4 & 1.1 \\
\hline & Quarter 3 & 4,177 & 2,341 & 1,836 & 284 & 145 & 139 \\
\hline & & 1.5 & 1.8 & 1.3 & 1.1 & 1.2 & 1.0 \\
\hline & Quarter 4 & 2,175 & 1,245 & 930 & 188 & 100 & 88 \\
\hline & & 0.8 & 1.0 & 0.6 & 0.7 & 0.8 & 0.6 \\
\hline \multirow[t]{10}{*}{2007} & Number of civil partnerships & 7,929 & 4,371 & 3,558 & 688 & 339 & 349 \\
\hline & $\begin{array}{l}\text { People forming a civil partnership per } \\
1,000 \text { unmarried population aged } 16 \text { and over }\end{array}$ & 0.7 & 0.8 & 0.6 & 0.6 & 0.7 & 0.6 \\
\hline & Quarter 1 & 1,552 & 901 & 651 & 112 & 49 & 63 \\
\hline & & 0.6 & 0.7 & 0.5 & 0.4 & 0.4 & 0.5 \\
\hline & Quarter 2 & 2,157 & 1,152 & 1,005 & 180 & 93 & 87 \\
\hline & & 0.8 & 0.9 & 0.7 & 0.7 & 0.8 & 0.6 \\
\hline & Quarter 3 & 2,680 & 1,399 & 1,281 & 245 & 119 & 126 \\
\hline & & 1.0 & 1.1 & 0.9 & 0.9 & 1.0 & 0.9 \\
\hline & Quarter 4 & 1,540 & 919 & 621 & 151 & 78 & 73 \\
\hline & & 0.6 & 0.7 & 0.4 & 0.6 & 0.7 & 0.5 \\
\hline \multirow[t]{10}{*}{2008} & Number of civil partnerships & 6,558 & 3,536 & 3,022 & 525 & 245 & 280 \\
\hline & $\begin{array}{l}\text { People forming a civil partnership per } \\
1,000 \text { unmarried population aged } 16 \text { and over }\end{array}$ & 0.6 & 0.7 & 0.5 & 0.5 & 0.5 & 0.5 \\
\hline & Quarter 1 & 1,132 & 641 & 491 & 98 & 54 & 44 \\
\hline & & 0.4 & 0.5 & 0.3 & 0.4 & 0.4 & 0.3 \\
\hline & Quarter 2 & 1,794 & 969 & 825 & 114 & 53 & 61 \\
\hline & & 0.7 & 0.7 & 0.6 & 0.4 & 0.4 & 0.4 \\
\hline & Quarter 3 & 2,241 & 1,151 & 1,090 & 195 & 83 & 112 \\
\hline & & 0.8 & 0.9 & 0.7 & 0.7 & 0.7 & 0.8 \\
\hline & Quarter 4 & 1,391 & 775 & 616 & 118 & 55 & 63 \\
\hline & & 0.5 & 0.6 & 0.4 & 0.4 & 0.4 & 0.4 \\
\hline
\end{tabular}

1 Civil partnership data are based on country of formation, population data are based on country of residence.

2 The Civil Partnership Act 2004 came into force on 5 December 2005 in the UK.

3 Rates for 2005 have been calculated on the basis that there were only 11 days in England and Wales and 12 days in Scotland on which couples could normally register a partnership.

4 Marital status estimates for England and Wales for mid-year 2005, 2006 and 2007 were revised on 30 April 2009 to include marriages abroad so rates may differ from those previously published.

p Rates for 2008 are provisional as they are based on revised mid-year 2007 marital status estimates.

Source: www.statistics.gov.uk/StatBase/Product.asp?vlnk=14675 Table 2, http://www.statistics.gov.uk/popest, http://www.gro-scotland.gov.uk/statistics/population

\section{Age at formation}

For both men and women, the number of civil partnerships formed in the UK fell in every age group in 2008 compared with 2007, with the largest percentage decreases in the older age groups (Figure 3). The average (mean) age at formation for male civil partners remained higher than for female civil partners in 2008, although the average age fell for both sexes compared with 2007. For men, the average age fell to 41.8 years in 2008 from 42.8 years in 2007 . For women, the average age fell to 40.0 years from 41.2 years. $^{6}$

Figure 4 shows the proportion of men and women forming civil partnerships in the UK each quarter by age group. In December 2005 and in the first quarter of 2006, more than half of all male civil partners and more than a third of all female civil partners were aged 50 and over. By the last quarter of 2006, less than a third (31 per cent) of male civil 


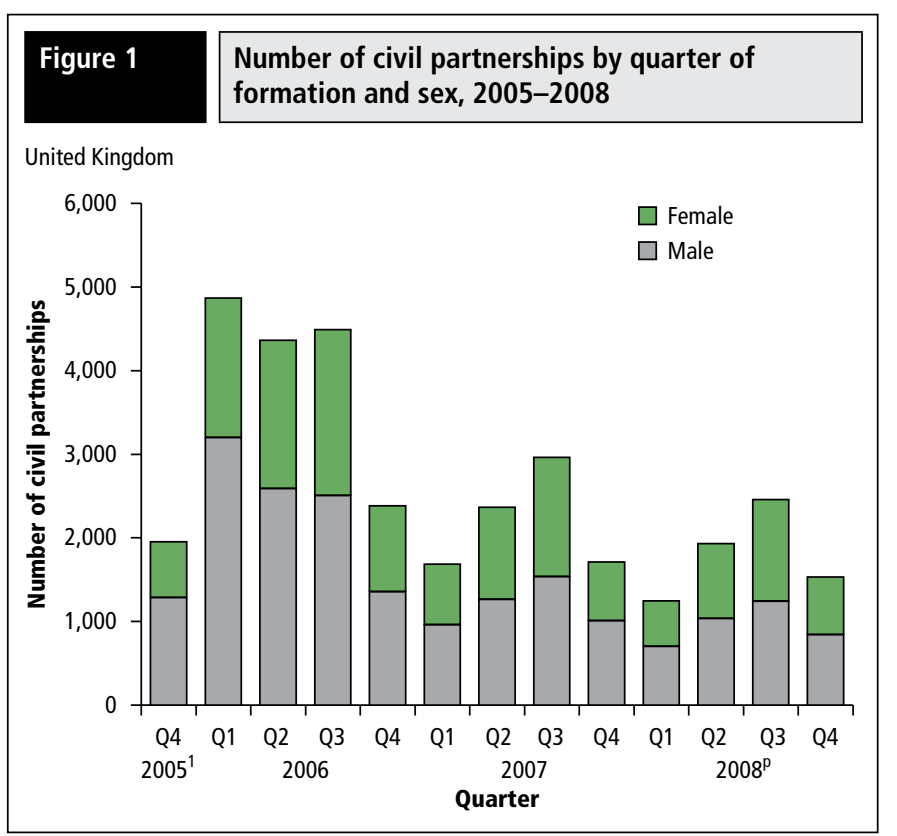

1 The Civil Partnership Act 2004 came into force on 5 December 2005 in the UK. p Figures for Northern Ireland and the UK for 2008 are provisional. Source: www.statistics.gov.uk/StatBase/Product.asp?vInk=14675 Table 1

partners and less than a quarter ( 24 per cent) of female civil partners were aged 50 and over.

The average age of all civil partners in 2008 was highest in England and Scotland (both 40.9 years) and lowest in Northern Ireland (39.3 years). In Wales the average age was 40.6 years. In England and Wales the average (mean) age gap between male civil partners increased to 8.2 years in 2008 from 7.7 years in 2007 . The average age gap between female civil partners increased to 5.7 years from 5.3 years.

With almost three in ten men ( 29 per cent) and just under a quarter of women (24 per cent) forming civil partnerships in 2008 in the West Midlands aged 50 and over, civil partners in this region were, on average, older than in other regions of the UK. People forming civil partnerships

\section{Figure 2 (a) 2 (n)} Number of civil partnerships by area of formation ${ }^{1}$ and sex, 2008

\section{United Kingdom}

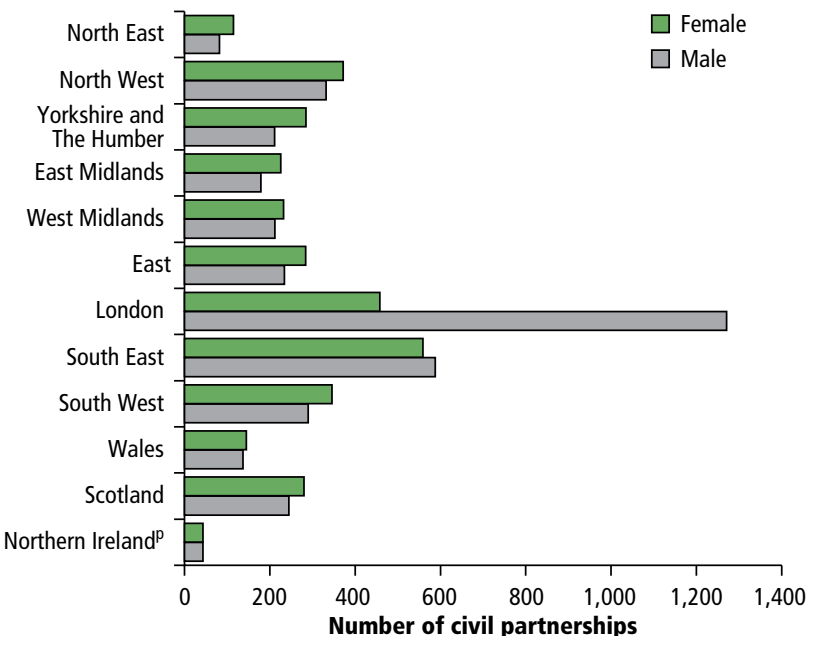

1 Data are based on area of formation and not area of residence.

p Figures for Northern Ireland and the UK for 2008 are provisional.

Source: www.statistics.gov.uk/StatBase/Product.asp?v/nk=14675 Table 3

in Yorkshire and the Humber and in London in 2008 were, on average, younger than those in other regions. Just under two in five women ( 38 per cent) entering a civil partnership in both Yorkshire and the Humber and in London were aged under 35 compared with 36 per cent in the UK as a whole. Only 9 per cent of women registering a civil partnership in Northern Ireland in 2008 were aged 50 and over; however, 40 per cent of women registering a civil partnership in Wales were aged under 35 .

\section{Area of formation}

As in 2007, London was the region within the UK with the highest number of registered partnerships in 2008. One-third of all male civil partners formed a civil partnership in London in 2008 whereas the region

\section{Figure 3} Number of civil partners by age group, 2007 and 2008

United Kingdom

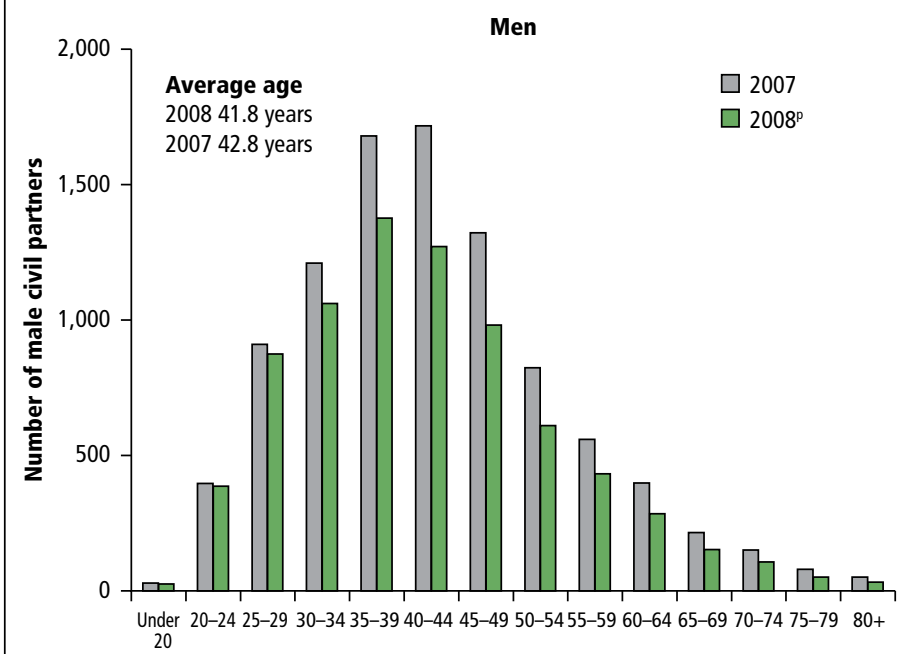

Age group

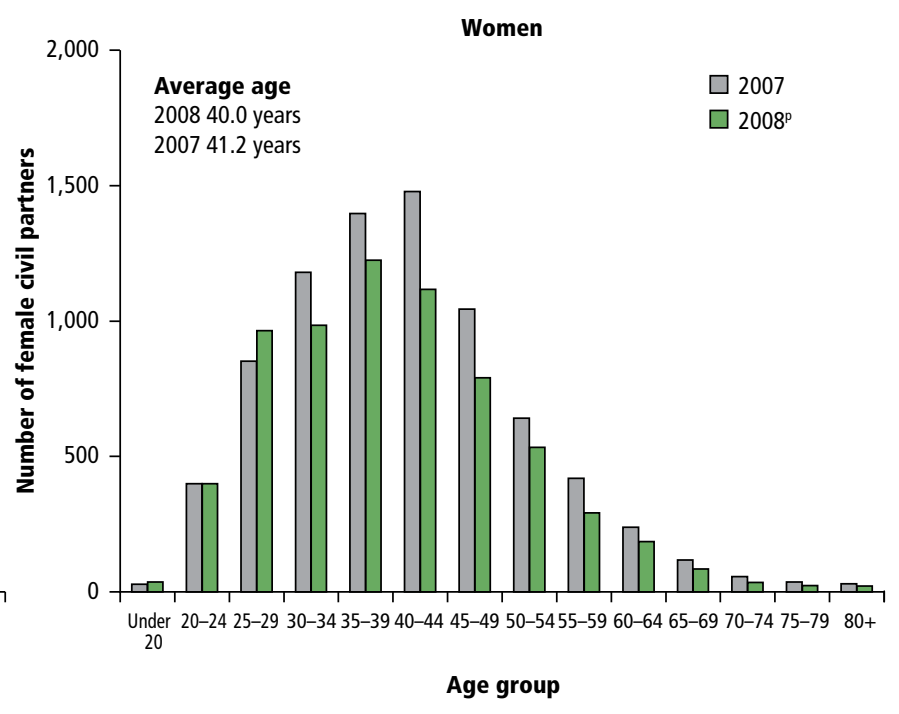

Age group

p Figures for Northern Ireland and the UK for 2008 are provisional. Source: www.statistics.gov.uk/StatBase/Product.asp?vInk=14675 Table 7 


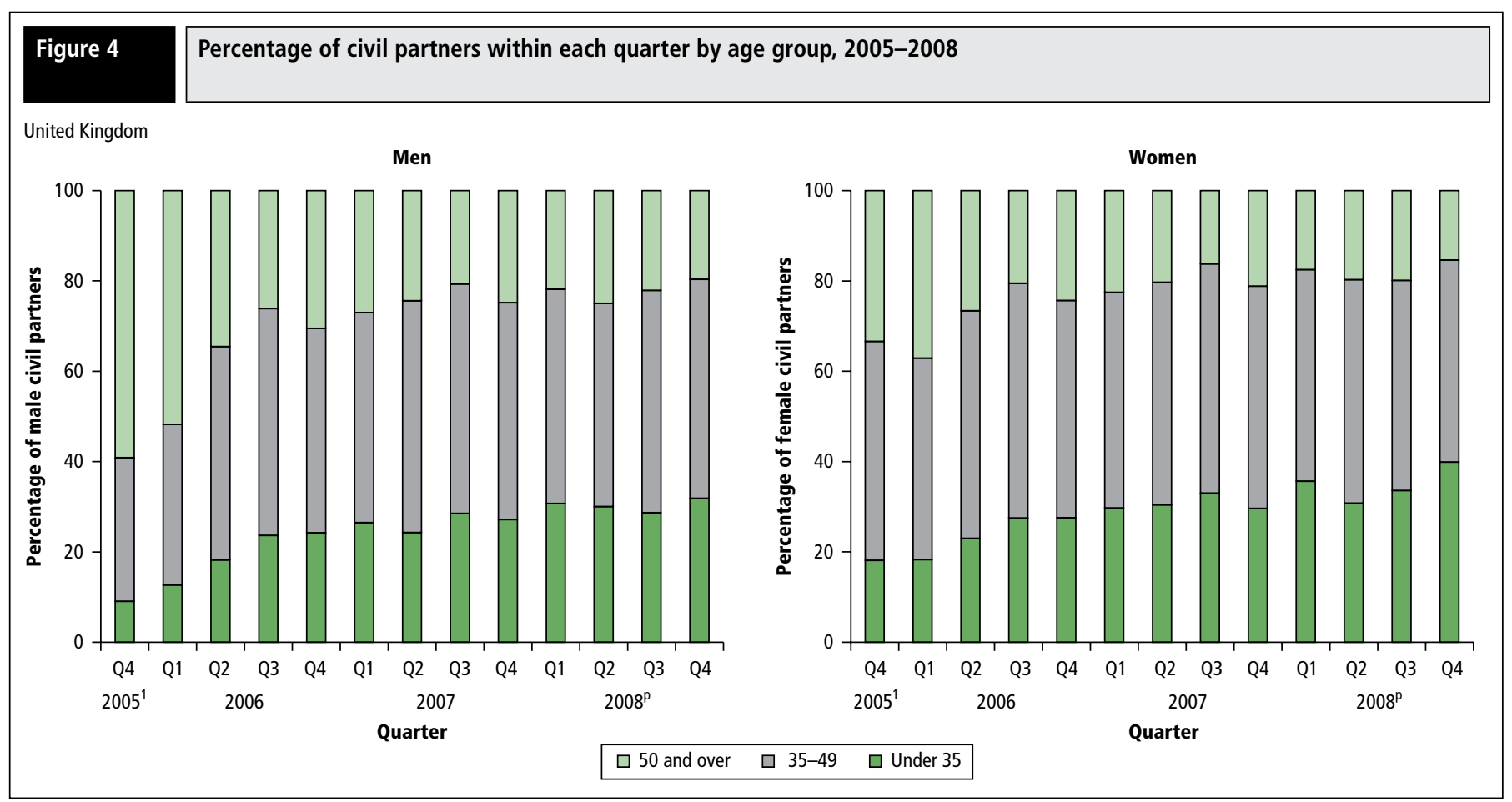

1 The Civil Partnership Act 2004 came into force on 5 December 2005 in the UK.

p Figures for Northern Ireland and the UK for 2008 are provisional.

Source: www.statistics.gov.uk/StatBase/Product.asp?vInk=14675 Table 8

accounts for only 12 per cent of the resident UK adult male population (Table 3). With 15 per cent of all male civil partnerships, the South East was the region with the second highest number and also the only other region in the UK in 2008 where a greater proportion of men formed a civil partnership compared with the resident adult male population.

As in 2007, the number of women forming civil partnerships in 2008 was more representative of the resident adult female population within each region. The South East and London together accounted for almost one-third ( 31 per cent) of all UK female civil partnerships in 2008 compared with 26 per cent of the resident adult female population.

\section{Previous legal partnership status}

The previous legal partnership status of a civil partner is defined as their legal marital or civil partnership status prior to giving notice of intention to form a civil partnership. A person wishing to register a civil partnership in the UK must either be single (never married or never

\begin{tabular}{|c|c|c|c|c|c|c|}
\hline Table 3 & fivil par & nd resident adul & ulation by ar & d sex, 2008 & & \\
\hline \multicolumn{7}{|l|}{ United Kingdom } \\
\hline $\begin{array}{l}\text { Countries, Government Office } \\
\text { Regions (within England) }\end{array}$ & $\begin{array}{l}\text { Total civil } \\
\text { partners }\end{array}$ & $\begin{array}{l}\text { Total population } \\
\text { aged } 16 \text { and over }{ }^{2}\end{array}$ & $\begin{array}{c}\text { Male } \\
\text { civil partners }{ }^{1}\end{array}$ & $\begin{array}{l}\text { Male population } \\
\text { aged } 16 \text { and over }{ }^{2}\end{array}$ & $\begin{array}{l}\text { Female } \\
\text { civil partners }{ }^{1}\end{array}$ & $\begin{array}{l}\text { Female population } \\
\text { aged } 16 \text { and over }{ }^{2}\end{array}$ \\
\hline UNITED KINGDOMp & 100 & 100 & 100 & 100 & 100 & 100 \\
\hline ENGLAND & 88 & 84 & 89 & 84 & 86 & 84 \\
\hline North East & 3 & 4 & 2 & 4 & 3 & 4 \\
\hline North West & 10 & 11 & 9 & 11 & 11 & 11 \\
\hline Yorkshire and The Humber & 7 & 8 & 6 & 9 & 9 & 8 \\
\hline East Midlands & 6 & 7 & 5 & 7 & 7 & 7 \\
\hline West Midlands & 6 & 9 & 6 & 9 & 7 & 9 \\
\hline East & 7 & 9 & 6 & 9 & 8 & 9 \\
\hline London & 24 & 12 & 33 & 12 & 14 & 12 \\
\hline South East & 16 & 14 & 15 & 14 & 17 & 14 \\
\hline South West & 9 & 9 & 8 & 9 & 10 & 9 \\
\hline WALES & 4 & 5 & 4 & 5 & 4 & 5 \\
\hline SCOTLAND & 7 & 9 & 6 & 8 & 8 & 9 \\
\hline NORTHERN IRELAND ${ }^{p}$ & 1 & 3 & 1 & 3 & 1 & 3 \\
\hline
\end{tabular}

Note: Percentages may not add up to 100 due to rounding.

1 Civil partnership data are based on area of formation and not area of residence.

2 Population data used to calculate percentages in this table were the latest available when these data were compiled: mid-year 2007 population estimates for the resident population of the UK.

p Civil partnership figures for Northern Ireland and the UK for 2008 are provisional.

Source: www.statistics.gov.uk/StatBase/Product.asp?vlnk=14675 Table 4, http://www.statistics.gov.uk/popest 
United Kingdom ${ }^{p}$
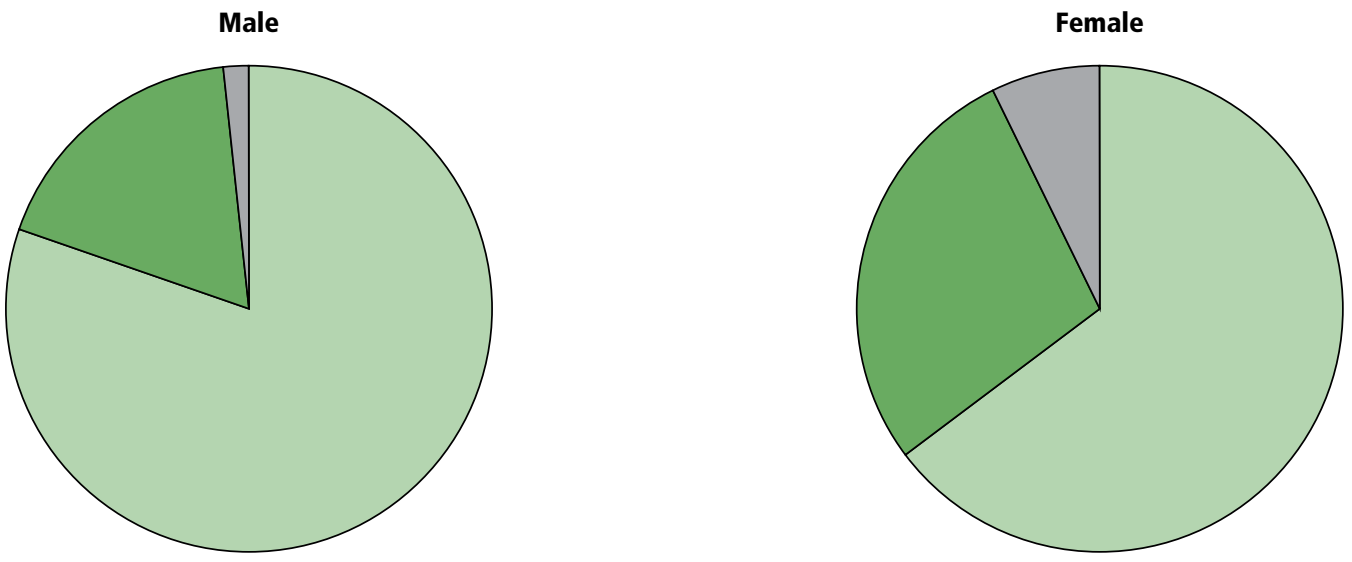

$\square$ Both single $^{1} \quad \square$ One single ${ }^{1}$, One previously in a legal partnership ${ }^{2} \quad \square$ Both previously in a legal partnership ${ }^{2}$

1 Single men and women are those who have never married or never formed a civil partnership.

2 Men and women who were previously in a legal partnership are those whose former marriage or civil partnership has been terminated either by dissolution or annulment or by the death of the spouse or civil partner.

p Figures for Northern Ireland and the UK for 2008 are provisional.

Source: www.statistics.gov.uk/StatBase/Product.asp?v/nk=14675 Table 11

formed a civil partnership) or have previously been in a legal partnership which has been terminated either by dissolution or annulment or by the death of the spouse or civil partner.

In the UK in 2008, 21 per cent of all female civil partners had previously been in a legal partnership, almost twice the proportion of all male civil partners (11 per cent). These proportions were similar to those for 2007. Forty people entering a civil partnership in the UK in 2008 had previously been in a civil partnership which had been terminated by dissolution or death. Less than one per cent of all people forming a civil partnership in 2008 were widowed. $^{7}$

A higher proportion of civil partners in Scotland (18 per cent) had previously been in a legal partnership compared with the other countries of the UK. Ten per cent of people registering a civil partnership in Northern Ireland had previously been in a legal partnership. The proportions for England and Wales were 15 per cent and 17 per cent respectively.

Men and women forming a civil partnership in the UK in 2008 who had previously been in a legal partnership tended to be older than those who were single; in particular widowed people tended to be older than those who had dissolved or annulled a previous marriage or civil partnership. Just under three quarters ( 74 per cent) of widowed men and almost half (49 per cent) of widowed women were aged 50 and over.

Figure 5 shows that the majority (four out of five) of UK male civil partnerships formed in 2008 were between two single men. More than three out of five ( 65 per cent) female civil partnerships were between two single women and over a quarter ( 28 per cent) involved a single woman forming a civil partnership with a woman who had previously been in a legal partnership. These proportions were similar to those for 2007.

\section{Civil partnership dissolutions}

To obtain a civil partnership dissolution in the UK, a couple must have been in either a registered civil partnership or a recognised foreign relationship for 12 months. There were 180 civil partnership dissolutions granted in the UK in 2008 compared with only 42 in 2007. Of these, 154 were in England, 12 in Wales, 14 in Scotland and none in Northern Ireland. On average, 8 civil partnerships were dissolved in the UK each month between January and March 2008, rising to 15 between

\section{Key findings}

- There were 7,169 civil partnerships formed in the UK in 2008, 18 per cent fewer than in 2007. The largest decrease was in Scotland (24 per cent) and the smallest was in Wales (4.1 per cent). Civil partnerships in England and in Northern Ireland fell by 18 per cent and 23 per cent

- In 2008, 88 per cent of UK civil partnerships were formed in England, 7.3 per cent in Scotland, 3.9 per cent in Wales and 1.2 per cent in Northern Ireland

- In 2008, civil partnership rates per 1,000 of the population legally able to form a civil partnership in England and Wales were 0.7 for men and 0.5 for women. In Scotland, the rates were 0.5 for men and 0.5 for women

- The proportion of UK male civil partnerships decreased to 53 per cent in 2008 from 55 per cent in 2007

- The average (mean) age of men forming a civil partnership in the UK in 2008 fell to 41.8 years from 42.8 years in 2007. For women the average age fell to 40.0 years from 41.2 years

- In 2008, one-third of all male civil partners registered their civil partnership in London, whereas the region accounts for only 12 per cent of the resident UK adult male population. Almost one-third of all female civil partners registered their civil partnership in the South East and London compared with 26 per cent of the resident UK adult female population

- In 2008, 11 per cent of men forming a civil partnership in the UK had previously been in a legal relationship compared with 21 per cent of women

- There were 180 civil partnership dissolutions granted in the UK in 2008, of which 64 were to male couples and 116 to female couples 
April and September and increasing again to 22 between October and December. ${ }^{8}$

There were more women than men dissolving a civil partnership in all countries of the UK in 2008. Scotland had the highest proportion of female civil partnership dissolutions compared to males ( 79 per cent and 21 per cent) and Wales had the lowest proportion, 58 per cent and 42 per cent respectively. The figures for England show a similar trend with 64 per cent of all dissolutions being to female couples and 36 per cent to male couples.

Fifty per cent of civil partners obtaining a dissolution in the UK in 2008 were aged between 35 and 49 years whereas only 11 per cent were aged 50 years and over. The figures for the UK show that a greater proportion of male civil partnership dissolutions were in the higher age group compared with females: 14 per cent of male civil partners dissolving were aged 50 years and over compared with only 9 per cent of females.

\section{Background notes}

1 There were 18 civil partnerships formed under special arrangements before these dates. These are included in the published figures. All were in England and Wales.

2 Figures for Northern Ireland and the UK for 2008 are provisional. The figures relate only to civil partnerships formed in the constituent countries of the UK. They will include non-UK residents who form a civil partnership in the UK but do not include civil partnerships of UK residents taking place abroad. Each year some overseas civil partnerships are recorded in the records held at the General Register Office for England and Wales (GRO). These fall into three main types; civil partnerships of armed forces personnel, civil partnerships that take place in certain UK consuls and civil partnerships deposited under Article 15 of the Civil Partnership (Registration Abroad and Certificates) Order 2005. According to GRO, in 2008 there were 114 civil partnerships formed overseas and registered by British registering authorities. There were also a further 4 partnerships which were recorded as 'foreign' partnerships and deposited under Article 15. The number of civil partnerships formed abroad and registered with GRO will only represent a small percentage of the total number of civil partnerships, or equivalent, entered into by UK nationals abroad in any one year.

3 Civil partnership data are based on country of formation and not country of residence. Figures for England and Wales are based on date of formation. Figures for Scotland and Northern Ireland are based on date of registration.

4 Population data were the latest available when these data were compiled and are based on the 2001 Census: mid-year 2007 population estimates for the resident population of the UK were published on 21 August 2008. Further information on population estimates can be found on the National Statistics website at: www.statistics.gov.uk/popest

5 Rates for 2008 are provisional. The population estimates by marital status used to calculate rates in this update are the latest available: revised mid-year 2005, mid-year 2006 and mid-year 2007 estimates for England and Wales to include marriages abroad were published on 30 April 2009; mid-year 2005 and mid-year 2006 estimates for Scotland were published on 28 July 2006 and 27 July 2007; mid year 2007 estimates for Scotland were published on 20 January 2009. Population estimates by marital status are not available for Northern Ireland and they are not produced at subnational level. Civil partnership status is not included in the mid-year population estimates by marital status

6 The average (mean) ages presented in this update are not standardised and therefore take no account of the structure of the population by age or legal partnership status.

7 Widowed men and women are those whose former marriage or civil partnership has been terminated by the death of the spouse or civil partner.

8 Figures for civil partnership dissolutions for 2008 are provisional. Data are based on country of dissolution and not country of residence. 